\title{
PROVOKASI SEKITAR TEOLOGI PEMBANGUNAN YANG KONTEKSTUAL ${ }^{1}$
}

\author{
W.I.M. Poli $\left.{ }^{2}\right)^{*}$ \\ 2) Guru Besar Emiritus Fakultas Ekonomi Universitas Hasanuddin Makassar \\ ${ }^{*}$ Penulis korespondensi: wimpoli40@gmail.com
}

\begin{abstract}
Abstrak
Teologi Pembangunan yang kontekstual berbicara tentang kemungkinan usaha membebaskan diri sendiri dan orang lain untuk mencapai tingkat kehidupan yang lebih bermakna, berdasarkan iman. Apa pun usaha pembangunan yang dilakukan, cirinya adalah eskatologis. Dimana pun orang Kristen berada, ia dipanggil oleh Kepala Gereja untuk menjadi mitra pembangunan di dalam masyarakat yang beradab, yang kian menjadi majemuk di era globalisasi. Di dalam masyarakat sedemikian ini, hubungan antar mitra pembangunan yang tepat adalah "I-Thou" ketimbang "I-It."

Kata kunci: Teologi Pembangunan yang Kontekstual; hubungan "I-Thou" dan "I-It"

Contextual Theology of Development speaks about possible efforts to overcome the unability of oneself and others to achieve a more meaningful life in one's own surrounding, based on one's faith. Whatever effort of development is undertaken, it is eschatological in nature. Wherever they are, Christians are called by Head of the Church to be partners of development within a civilized society, which is becoming more and more pluralistic in the era of globalization. Within such kind of society, the proper relationship with other partners of development is "I-Thou" instead of "I-It."
\end{abstract}

Keywords: Contextual Theology of Development; "I-It" and "I-Thou" relationship

\section{Pendahuluan}

Sebanyak 1.918 anak di Nusa Tenggara Timur menderita gizi buruk selama Januari-Mei 2015. Tercatat 11 anak berusia di bawah lima tahun meninggal akibat gizi buruk. Selain itu masih ada 21.134 anak balita yang mengalami kekurangan gizi. Kompas, 23 Juni 2015.

\footnotetext{
${ }^{1}$ Orasi Ilmiah pada acara Wisuda ke-41 Sekolah Tinggi Theologia Jaffray, Makassar, 12 September 2015.
} 


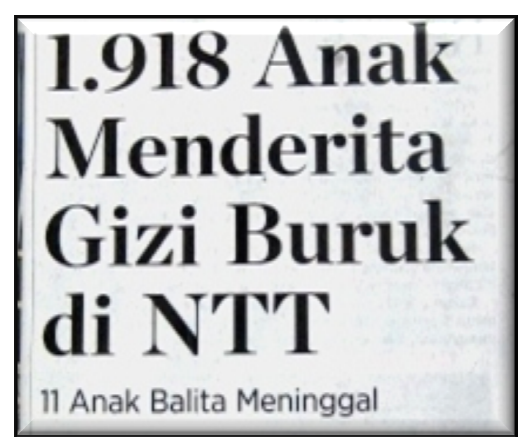

Gambar l. Potongan Harian Kompas, 23 Juni 2015.

Jika kita tergugah oleh potongan berita di atas, lalu menanggapinya berdasarkan iman, maka kita sedang berteologi pembangunan yang kontekstual. Pesan yang relevan ialah: Janganlah khotbah kita berputarputar di atas Israel masa Perjanjian Lama saja, tanpa pernah mendarat di bumi Indonesia pada abad XXI ini. Karena itu, judul orasi ilmiah ini adalah: Provokasi Sekitar Teologi Pembangunan yang Kontekstual. Tujuan orasi ini ialah: tergugahnya pikiran dan perasaan para hadirin, untuk berbuat sesuatu di lingkungan kerjanya, kini dan di sini, menuju kehidupan yang lebih bermakna berdasarkan iman.

Sebagai sebuah provokasi, orasi ini lebih banyak mengajukan pertanyaan ketimbang menjawabnya.

1. Sebuah Pola Pikir

2. Dari Masa Depan ke Masa Kini

3. Dari Masa Kini ke Masa Depan

4. Partisipasi dalam Pembangunan

5. Keberpihakan Tuhan

6. Kerendahan Hati

7. Realitas Baru

8. Kesimpulan

\section{Sebuah Pola Pikir}

Pikiran saya tersentak pada tanggal 1 Juni 2015, jam 08.50 pagi, oleh telpon dari Pendeta Dr. Daniel Ronda. Saya diminta untuk memberikan orasi ilmiah di STT Jaffray pada 12 September 2015. Pada mulanya muncul di dalam pikiranku tentang akan adanya orasi ilmiah pada 12 September 2015. Kemudian, sejak 1 Juni 2015 tersebut, dalam diriku ada pikiran yang terus diolah tentang orasi ilmiah ini. Akhirnya, ada sebuah naskah yang dapat disajikan dalam pertemuan hari ini. Singkatnya, pada mulanya ada sebuah titik di masa depan yang hendak dicapai. Kemudian, ada sebuah proses berpikir sejak 1 Juni 2015, untuk mencapai sebuah titik di masa depan, yaitu hari ini. Bergerak dari masa depan ke masa 
kini, kemudian memikirkan masa depan lagi, adalah apa yang saya alami. Pengalaman itu ada karena adanya pola pikir dan perilaku yang eskatologis. Hal yang sama juga terjadi dalam perjalanan sejarah Gereja di dunia ini. Masa depan yang bermakna dihubungkan dengan tindakan hari ini. Tindakan hari ini baru bermakna jika dihubungkan dengan masa depan yang hendak dicapai.

Dengan pola pikir dan pengalaman itu, saya juga mau menyentak pikiran para hadirin pada hari ini. Andaikata saya dibolehkan menata kembali Perjanjian Baru, saya mau memulainya bukannya dengan Injil Matius, melainkan dengan Kitab Wahyu. Saya mau mulai dengan gambaran tentang Yerusalem Baru, ke arah mana sejarah keselamatan berkembang. Kemudian barulah dimunculkan Lukas 2, yang bercerita tentang kelahiran Kristus. Lalu, di antara keduanya, dimunculkan Kisah Para Rasul. Di antara kedua titik waktu tersebut, dapat dimunculkan apa pun yang kita kerjakan di dalam dunia ini, termasuk apa yang dikerjakan keluarga besar STT Jaffray, kini dan di sini.

Di dalam konteks kegiatan STT Jaffray itu, saya hadir di sini sebagai dosen yang mengajarkan matakuliah Kepemimpinan, untuk jenjang pendidikan Strata 2, dan Teologi Pembangunan, untuk jenjang pendidikan Strata 3. Kedua mata kuliah ini diajarkan dengan pola pikir eskatologis, dalam konteks pembangunan Indonesia. Karena itu, judul orasi ini adalah Provokasi Sekitar Teologi Pembangunan yang Kontekstual.

\section{Dari Masa Depan ke Masa Kini}

Sehubungan dengan pemikiran tentang pembentukan kehidupan masa depan yang lebih bermakna, dapat dikemukakan di sini pemikiran dari dua karya yang berbeda pendekatannya tetapi sama tujuannya, yaitu karya George Orwell dari Inggris, dan Paul D. Raskin dari Amerika Serikat. Pendapat keduanya, yang berasal dari belahan bumi yang berbeda, dimaksudkan sebagai masukan bagi kita masing-masing untuk menentukan pendapat dan tindakan sendiri, kini dan di sini, berdasarkan iman yang dianut. Itulah ciri Teologi Pembangunan yang Kontekstual.

\subsection{George Orwell: Nineteen Eighty-Four}

Buku George Orwell ${ }^{2}$ (1903-1950), yang berjudul Nineteen Eighty-Four, ditulis setelah Perang Dunia II dan diterbitkan pertama kali pada tahun 1949. Dalam situasi setelah Perang Dunia II, Orwell berbicara tentang tahun 1984 yang belum ada, tetapi yang diperhitungkan akan ada, sesuai

\footnotetext{
${ }^{2}$ George Orwell adalah nama pena pengarang berkebangsaan Inggris, yang nama aslinya adalah Eric Arthur Blair.
} 
dengan perkembangan sejarah dunia yang diketahuinya. Ia melukiskan tentang gejala rezim politik yang otoriter, yang dinamakannya Big Brother. Setelah Perang Dunia II, gejala Big Brother ini muncul di berbagai negara maju. Secara sistematis dan luas, rezim-rezim otoriter tersebut mengeksploitasi pikiran dan tindakan rakyatnya sendiri untuk mempertahankan kekuasaannya. Uraian Orwell sangat menakutkan. Tujuan karya Orwell ialah: tercapainya pemahaman yang luas tentang kejamnya eksploitasi Big Brother, sehingga dapat dimunculkan kekuatan massa untuk melawannya. Ini adalah sebuah cara provokasi dari George Orwell.

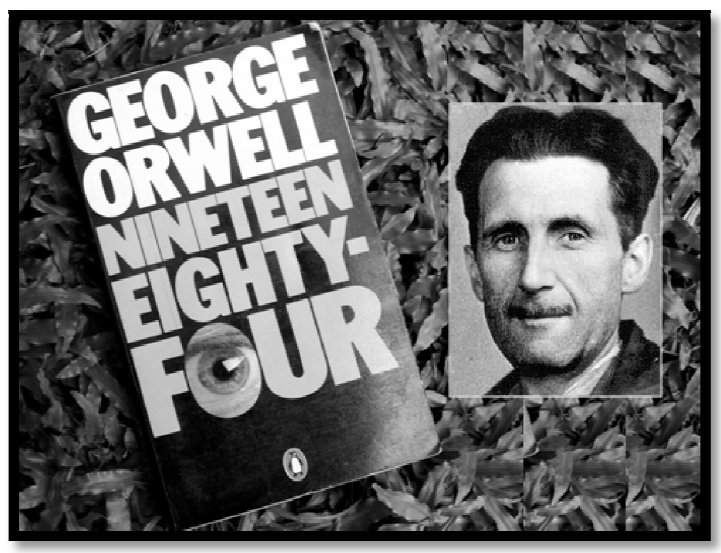

Gambar 2. George Orwell dan karyanya. ${ }^{3}$

Hasil pengamatan Soedjatmoko (1922-1989) yang disampaikannya dalam rangkaian Ceramah Ishizaka di Jepang pada bulan Maret 1979, ${ }^{4}$ menunjukkan bahwa rezim-rezim otoriter itu pada awalnya tidak otoriter. Mereka muncul sebagai pemerintah yang membela kepentingan rakyat, dan gandrung memajukan pembangunan bangsanya. Tetapi, lambat-laun mereka mengembangkan sikap tidak mau dikritik, karena kritik terhadap pemerintah dapat mengganggu stabilitas politik dan keberhasilan pembangunan. Dua kasus sejarah yang dijadikan contoh oleh Soedjatmoko adalah rezim otoriter Jerman dan Jepang menjelang Perang Dunia II. Dengan dua kasus itu ia bertanya: pembangunan yang bagaimanakah, yang dapat mencegah munculnya kembali rezim-rezim otoriter sedemikian itu. Karena itu, bagi orang yang peduli terhadap pembangunan untuk kepentingan masyarakat, seyogianya juga peduli

\footnotetext{
${ }^{3}$ Penguin Books, Harmondsworth, Middlesex, England, 1954.

${ }^{4}$ Naskah asli rangkaian ceramah tersebut diteribitkan dalam bahasa Inggris oleh Simul Press, Tokyo. Naskah terjemahan dalam bahasa Indonesia diterbitkan LP3ES pada tahun 1984 di bawah judul Pembangunan dan Pembebasan.
} 
terhadap kecenderungan rezim penguasa membatasi kebebasan rakyatnya atas nama keberhasilan pembangunan bangsa dan negara. Rakyat dari negara-negara yang sudah merdeka mungkin belum mengalami kebebasan di dalam kemerdekaannya. Soedjatmoko membahas tentang kemerdekaan dan pembebasan di dalam bukunya, Etika Pembebasan. ${ }^{5}$

Pertanyaan Renungan: Bagaimanakah pengalaman Indonesia di waktu yang lalu, kemungkinan pengalamannya di masa depan, dan peranan apakah yang seyogianya dijalankan masyarakat dan lembaga-lembaganya yang ada, sebagai pelaku pembangunan yang bertanggung-jawab agar dapat dihindari munculnya rezim yang otoriter?

\subsection{Paul D. Raskin: Laporan dari Masa Depan}

Kini, muncul berbagai karya lain yang memberikan laporan tentang masa depan yang ideal, yang merangsang kekuatan massa dari masa kini untuk bertindak mencapai masa depan yang ideal tersebut. Salah satunya adalah karya Paul D. Raskin (1942 - ), yang berjudul The Great Transition; A Report from the Future, yang diterbitkan pada tahun 2006. "Laporan dari Masa Depan" itu seakan-akan ditulis dari sebuah kota yang bernama Kota Mandela. Nama kota fiktif ini pasti dihubungkan dengan nama Nelson Mandela (1918-2013), pejuang kemanusiaan dari Afrika Selatan, penggagas dan pelaku kehidupan bersama yang damai di dalam masyarakat majemuk, tanpa prasangka SARA. ${ }^{6}$

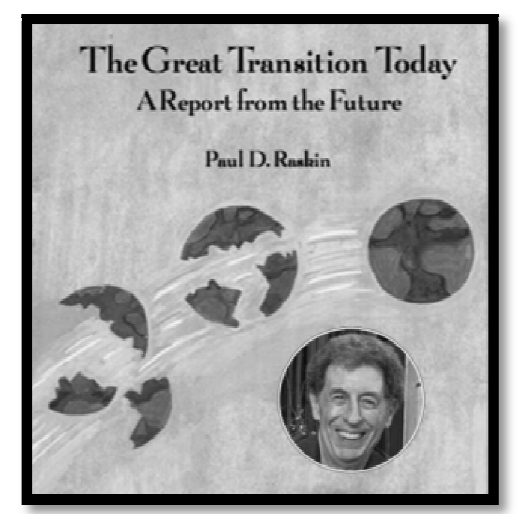

Gambar 3. Paul D. Raskin dan karyanya. ${ }^{\top}$

\footnotetext{
${ }^{5}$ Soedjatmoko, Etika Pembebasan. LP3ES, Jakarta, 1984.

${ }^{6}$ Suku-Agama-Ras. Pencipta isitilah SARA adalah Laksamana Sudomo, petinggi pemerintah dengan berbagai jabatannya pada pemerintahan Presiden Suharto di masa Orde Baru.

${ }^{7}$ Diterbitkan Tellus Institute, Boston, MA, 2006.
} 
Berbeda dari buku George Orwell, buku Raskin ini menggambarkan masa depan ideal yang dapat dicapai pada tahun 2084. Penulisnya seakan-akan mau membandingkan gambaran tahun 1984, yang menakutkan, dengan gambaran tahun 2084, yang menggembirakan. Ini adalah cara provokasi dari Raskin. Perbedaan keduanya adalah seperti perbedaan neraka dan surga. Pendekatan mana yang hendak kita pilih untuk pembangunan, kini dan di sini, dan apa alasan teologisnya?

\subsection{Gambaran Ideal Masa Depan}

Pengalaman masa lalu, khususnya pengalaman abad XX, dengan gamblang telah menunjukkan hal-hal negatif yang terjadi di dalam perkembangan sejarah, yaitu: konsumerisme, individualisme, dan kerusakan lingkungan alam. Ketiganya adalah tritunggal penyebab malapetaka pembangunan. Hal-hal negatif ini telah melahirkan kekuatan yang melawannya. Kekuatan perlawanan tersebut kini kian menggelinding, membesar, mengglobal, yang secara keseluruhan diidentifikasi sebagai kekuatan "Transisi Besar" (Great Transition) ke masa depan yang ideal, yaitu tercapainya tiga tujuan bersama secara terpadu: (1) meningkatnya mutu kehidupan; (2) meningkatnya solidaritas masyarakat yang beradab; dan (3) lestarinya lingkungan alam. Hubungan antara masa kini dan masa depan yang ideal tersebut dapat divisualisasikan melalui Gambar 4.

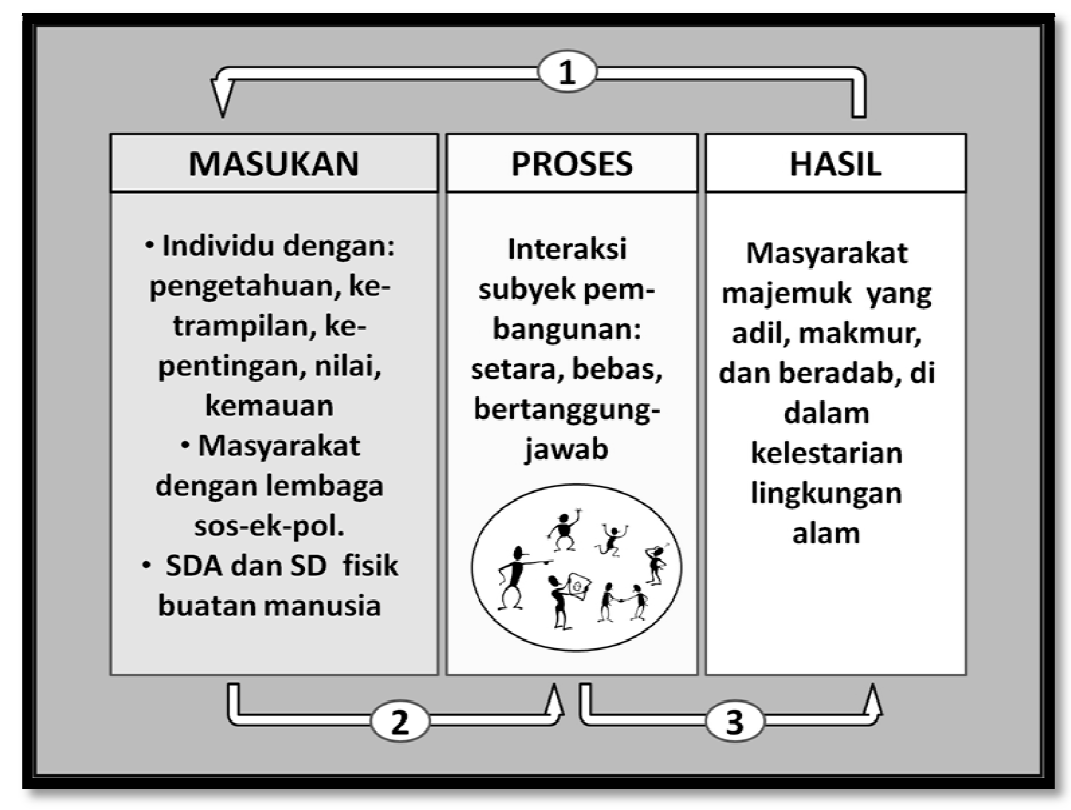

Gambar 4. Hubungan Sistemik Masa Depan dan Masa Kini. 
Meningkatnya mutu kehidupan, melampaui mutu kehidupan yang dicapai melalui pemenuhan kebutuhan fisik saja. Pola pikirnya beralih dari having more ke becoming more; dari memiliki lebih banyak ke menjadi lebih bermakna. Kehidupan yang lebih bermakna terjadi di dalam hubungan dengan orang lain, secara beradab, di dalam kelestarian lingkungan alam. Kemungkinan tercapainya ketiga tujuan bersama tersebut di masa depan sedemikian besarnya, sehingga dapatlah digubah sebuah skenario, yaitu sebuah cerita tentang masa depan yang ideal tersebut, dan dilaporkan pencapaiannya ke generasi masa kini. Itulah sebabnya, sub-judul bukunya adalah: A Report from the Future. Bandingkanlah Report from the Future ini dengan sebuah laporan lain tentang masa depan, yaitu Yerusalem Baru di dalam Kitab Wahyu. Perbedaan antara masa depan yang ideal dengan masa kini yang belum ideal, potensial menghasilkan sebuah ketegangan kreatif di dalam diri kita masing-masing.

Pertanyaan Renungan: Apakah laporan tentang Yerusalem Baru, di dalam Kitab Wahyu, menggairahkan kita dalam ke-giatan pembangunan Indonesia, kini dan di sini?

\section{Dari Masa Kini ke Masa Depan}

\section{3.l. Modal Masa Kini}

Pencapaian gambaran masa depan terjadi dengan menggunakan apa yang sudah kita warisi dari masa lalu sebagai masukan. Masukan ini adalah modal, yang berjenjang eksistensinya.

Pertama, ada individu, dengan pengetahuan, ketrampilan, kepentingan, nilai, dan kemauan yang ada padanya. Modal individual ini adalah hasil proses sosialisasi dan inkulturasi yang dialami individu di lingkungannya sejak ia dilahirkan, terutama pada usia dininya. Usia dini adalah usia kritis ketika mana terbentuk nilai-nilai tertentu di dalam diri seseorang, yang menjadi modal pengembangan dirinya di masa depan.

Kedua, ada masayarakat dengan lembaga-lembaga sosial-ekonomipolitik, yang menjadi rambu-rambu berpikir dan berperilaku para anggotanya, yang langsung berpengaruh pada proses sosialisasi dan inkulturasi tersebut di atas.

Ketiga, ada modal sumberdaya alam dan sumberdaya fisik buatan manusia, yang dipadukan dengan kedua modal pertama dalam proses pembangunan.

Dalam hal sumberdaya alam, Indonesia termasuk negara yang kayaraya sumberdaya alamnya, tetapi tergolong negara yang miskin, dibandingkan dengan tetangganya, Singapura. Ketika merdeka pada tahun 1959, Singapura sama miskinnya dengan Indonesia. 
... di tahun 1959, Singapura adalah suatu negara yang miskin, dengan tingkat pertumbuhan penduduk sebesar 4,6\% per tahun. Masyarakat Singapura ketika itu terutama terdiri atas kaum buruh tidak tetap yang rendah tingkat pendidikannya, para penarik trishaw (angkong), penjaja dan para penunggu toko, yang menghuni salah satu kawasan kumuh yang terpadat di dunia. Kini, Singapura adalah salah satu negara industri baru (new industrialist country) yang terkemuka. Dari mana datangnya perubahan ini ${ }^{8}$

Pertanyaan Renungan: Apakah ada alasan teologis tentang pengembangan dan penggunaan ketiga modal pembangunan tersebut di atas, dan bagaimana penerapannya dalam proses pembangunan, kini dan di sini?

\subsection{Proses Pembangunan}

Dengan menggunakan tiga modal tersebut di atas berlangsunglah proses pembangunan, yang pada dasarnya adalah interaksi manusia, sebagai subyek pembangunan yang setara, bebas, dan bertanggungjawab, untuk mencapai gambaran masa depan yang diinginkan. Interaksi ini berlangsung di dalam tatanan lembaga sosial-ekonomi-politik yang ada, sebagai bagian dari kekuatan Transisi Besar, menuju gambaran masa depan yang diinginkan. Interaksi manusia ini adalah interaksi dalam masyarakat majemuk.

Pertanyaan Renungan: Apakah ada alasan teologis tentang partisipasi dalam proses pembangunan di Indonesia sekarang ini, dan bagaimana penerapannya, kini dan di sini?

\section{Partisipasi dalam Pembangunan}

Tidak ada seorang pun di antara kita yang dapat memilih bukannya berada di Indonesia pada awal abad XXI ini, melainkan pada abad XIX atau abad XXII. Kita berada kini dan di sini, ketika mana masalah pokok bangsa kita adalah kemiskinan, yang belum dapat diatasi secara tuntas setelah 70 tahun merdeka. Bagaimanakah seyogianya partisipasi Kristen dalam mengatasi masalah kemiskinan di Indonesia sekarang ini? Sekali lagi, jawaban terhadap pertanyaan ini berciri Teologi Pembangunan yang Kontekstual.

\subsection{Akal dan Iman}

Untuk membangun jawaban terhadap pertanyaan tersebut, marilah kita mengacu pada sebuah peristiwa sejarah yang dapat dibaca di dalam

\footnotetext{
${ }^{8}$ W.I.M. Poli, Manajemen Stratejik melalui Cerita Kecil, $2011: 11$.
} 
Matius 14: 13 -21, Markus 6: 30-44, Lukas 9 : 10-17, dan Yohanes 6: 1-13. Setelah Kristus memberikan makanan rohani kepada 5.000 orang yang tampak seperti kawanan domba yang tidak bergembala, muncullah kegelisahan yang masuk akal di pihak para murid-Nya. Hari mulai malam, dan tempat di mana mereka berada adalah tempat yang sunyi, jauh dari kampung-kampung lainnya. Mereka mengusulkan agar orang banyak itu disuruh pulang agar mereka dapat membeli makanan di tempat-tempat sekitarnya. Usul yang masuk akal ini ditanggapi Kristus dengan tanggapan yang tidak masuk akal para murid-Nya. Dengan sengaja Kristus menyuruh mereka memberikan makan kepada 5.000 orang yang ada. Karena perintah itu tidak masuk akal, salah seorang murid memberikan lagi alasan yang masuk akal. Katanya, walau pun mereka punya uang sebanyak dua ratus dinar, roti yang dibeli pasti sedikit saja jumlahnya, sehingga tidak dapat mengenyangkan 5.000 orang. Tanggapan lanjutan dari Kristus ialah, mereka harus lihat apa yang ada, bukan apa yang tidak ada pada mereka. Setelah dilihat, ternyata hanya ada lima ketul roti dan dua ekor ikan, milik seorang anak kecil, bukan milik Petrus, sang nelayan, atau Yudas sang bendahara. Setelah apa yang ada itu diserahkan dan doa diucapkan, maka dari dalam tangan Kristus 5.000 orang dapat dikenyangkan, dan sisanya dapat dikumpulkan sebanyak 12 bakul. Maka, kini kita dapat rumuskan sebuah persamaan yang tidak masuk akal, tetapi yang sudah menjadi kenyataan, yaitu: $(5+2)=(5.000+12)$. Melampaui batas akal, kita masuk ke dalam wilayah iman. Maka, persamaannya harus ditulis kembali menjadi sebuah persamaan teologi kontekstual, yaitu: $(5+2)+$ iman $=(5.000+12)$. Pertanyaan yang sangat mendasar bukanlah apa dan berapa banyak yang kita miliki, yang dibutuhkan untuk pembangunan di sekitar kita, melainkan: apakah yang ada pada kita itu sedia diserahkan ke dalam tangan Tuhan untuk pemenuhan kebutuhan orang banyak?

Mungkin saja kita bertanya: Mengapa Kristus tidak langsung saja meminta apa yang ada pada murid-murid-Nya, mendoakannya, lalu membagikannya untuk mengenyangkan 5.000 orang? Dengan akal dapat kita lihat kembali sebuah proses pendewasaan iman yang berlangsung tahap demi tahap. Mulai dari tahap rasional tanpa iman, sampai ke tahap rasional dengan iman. Iman tidak lahir secara tiba-tiba, tanpa dialog, pengalaman dan perenungan, yang akhirnya bermuara pada eksistensi pribadi yang mandiri. Maka, pembangunan adalah usaha manusia membebaskan diri dan orang lain dari ketidak-mampuannya, menuju kehidupan bersama yang lebih bermakna di dalam lingkungannya.

Dari apa yang dikemukakan di atas dapat diturunkan rumusan tentang Teologi Pembangunan yang Kontekstual sebagai uraian tentang usaha manusia membebaskan diri dari ketidakmampuan sendiri dan 
orang lain, menuju kehidupan bersama yang lebih bermakna di dalam lingkungannya, berdasarkan iman yang dianut.

\section{Teologi Pembangunan yang Kontekstual adalah uraian tentang usaha manusia membebaskan diri dari ketidakmampuan sendiri dan orang lain, menuju kehidupan bersama yang lebih bermakna di dalam lingkungannya, berdasarkan iman yang dianut.}

Pembebasan diri dari ketidakmampuan tersebut tidak dapat mengandalkan usaha satu orang saja, betapa besar sekali pun orangnya. Sejarah adalah hasil karya bersama banyak orang, entah mereka saling tahu dan saling kenal atau tidak. Semua pelaku pembangunan adalah mitra pembangunan yang seyogianya saling menerima dan saling mengisi, terutama di abad globalisasi ini.

Pertanyaan Renungan: Siapakah mitra pembangunan kita, dan bagaimanakah pola hubungan kerja kita selama ini?

\subsection{Masuk ke Dalam Dunia}

Kini, pola kehidupan masyarakat kota bukan hanya ada di kota-kota besar. Polanya sudah menyebar ke kota-kota kecil dan kampungkampung di seluruh dunia, termasuk di Indonesia. Urbanisasi tidak hanya diartikan sebagai mengalirnya penduduk dari desa ke kota, melainkan juga mengalirnya pola kehidupan masyarakat kota ke masyarakat desa. Televisi, telpon genggam, dan iklan ada di mana-mana. Alat-alat komunikasi modern itu menyebarkan informasi-informasi yang sama ke mana-mana, yang antara lain melahirkan inspirasi dan aspirasi ke arah konsumerisme. Misalnya, di dunia hiburan, tayangan-tayangan TV, Video dan HP bersaingan ketat dengan informasi yang disampaikan melalui khotbah dan pelajaran agama. Mana yang menang? Kita dapat dengan gampang menjawab pertanyaan ini melalui pengalaman pribadi kita masing-masing.

Salah satu akibat lain dari revolusi teknologi komunikasi, transportasi dan informasi ialah perpindahan penduduk dari satu lokasi ke lokasi lain menjadi lebih mudah dan lebih intensif. Akibatnya, kian tinggi peluang perjumpaan arus manusia dengan berbagai perbedaannya. Kontak antar anggota masyarakat yang majemuk menjadi kenyataan yang tidak terhindarkan. Kontak yang meningkat itu sekaligus meningkatkan peluang kerjasama mau pun benturan nilai, pendapat dan kepentingan. Dalam keadaan demikian kita harus berbicara tentang tujuan dan cara mencapai tujuan pembangunan, menuju kehidupan bersama yang lebih bermakna. Apa alasan teologisnya? 
Jawaban terhadap pertanyaan ini antara lain dapat diturunkan dari isi Doa Imam Besar di Taman Getsemani, menjelang penangkapan dan penyaliban-Nya. Ia antara lain mendoakan murid-murid-Nya yang sedang tertidur. Ia tidak meminta agar mereka dikeluarkan dari dunia ini, melainkan mengutus mereka ke dalam dunia. Bukan saja Petrus dan kawan-kawannya yang didoakan Kristus untuk masuk ke dalam dunia ini. Katanya:

... bukan untuk mereka ini saja Aku berdoa, tetapi juga untuk orang-orang, yang percaya kepada-Ku oleh pemberitaan mereka ... (Yoh. 17:20).

Tegasnya, sebelum kita dilahirkan, kita sudah didoakan, untuk masuk ke dalam dunia, yaitu masyarakat urban yang kian majemuk di abad XXI ini. Bertemu dan berdialog dengan orang lain di dalam proses pembangunan bangsa dan negara adalah sebuah kemutlakan.

Bertemu dan berdialog dengan orang lain di dalam proses pembangunan bangsa dan negara adalah sebuah kemutlakan.

Jika demikan halnya, bagaimanakah dialog antara para pelaku pembangunan tersebut seyogianya berlangsung?

\subsection{Dialog Mitra Pembangunan}

Tentang pertemuan dan dialog antar mitra pembangunan, menuju kehidupan bersama yang bermakna, salah seorang pemikir besar abad XX, Martin Buber (1878-1965), mengatakan bahwa "kehidupan yang sebenarnya adalah perjumpaan", dan makna kehidupan kita berasal dari keterhubungan kita dengan orang lain. Kian hilang keterhubungan tersebut, kian hilang makna kehidupan kita.

Sehubungan dengan keterhubungan yang bermakna tersebut, Buber mengemukakan pendapatnya tentang dua pola hubungan, yang dinamakannya hubungan "I-It" dan "I-Thou." Di dalam bahasa aslinya, Jerman, kedua hubungan tersebut adalah Ich-Es dan Ich-Du. ${ }^{9}$ Buber tidak memandang dirinya sebagai filosof atau teolog. Alasannya, ia tidak tertarik pada gagasan, tetapi pengalaman pribadi, dan bukannya berbicara tentang Tuhan, melainkan pengalaman berhubungan dengan

\footnotetext{
${ }^{9}$ Buku Martin Buber, Ich und Du, terbit pada tahun 1923. Terjemahannya menjadi I and Thou, dikerjakan Ronald Gregor Smith dan diterbitkan T. \& T. Clark, Edinburgh, pada tahun 1937. Terjemahan ini dapat diunduh gratis dari http://www.bahaistudies.net/asma/iandthou.pdf.
} 
Tuhan. Katanya, orang hanya dapat berjumpa dengan Tuhan ketika ia berhubungan dengan orang lain dengan pola "I-Thou" (subyek dengan subyek hidup yang setara), bukan "I-It" (subyek hidup dengan obyek mati yang tidak setara).

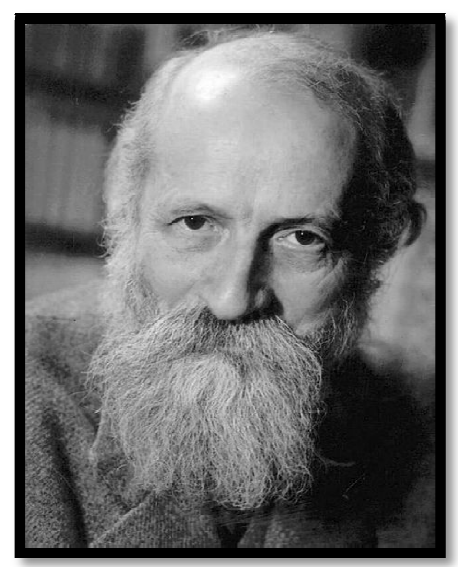

Gambar 5. Martin Buber (1878-1965).

Sebagai ilustrasi, pemikiran Buber di atas dapat dikemukakan pertemuan antara orang Aborigin di Australia dengan para pendatang, yaitu orang kulit putih dari Barat. Orang Aborigin tidak dapat menerima pandangan orang Barat yang rasional, yang mengajarkan mereka menebang pohon, membuat papan, dan membangun rumah yang permanen, ketimbang hidup mengembara dari satu tempat ke tempat lain. Itu adalah pola pikir dan perilaku "I-It": manusia sebagai subyek yang mandiri, dan alam sebagai obyek yang dieksploitasi. Orang Aborigin memandang pohon sebagai tempat yang sakral, tempat bersemayam roh leluhurnya. Itu adalah pola pikir dan perilaku "I-Thou": manusia dan alam adalah subyek yang setara. Menebang pohon berarti menghina roh leluhurnya. Itulah rasionalitas orang Aborigin, yang berbeda dari rasionalitas para pendatang dari luar Australia. Ketika orang lain, yang berbeda pendapat, berdialog dengan mereka, seyogianya tujuan dialog bukanlah mene-mukan pendapat mana yang benar dan mana yang salah, melainkan apa pendapat masing-masing pihak, yang dapat membantu hubungan yang saling memahami antara subyek pembangunan yang setara kedu-dukannya: subyek berhadapan dengan subyek. Demikian juga halnya dalam dialog antara umat beragama tentang pembangunan di Indonesia. Tujuannya bukannya menyepakati pendapat mana yang baik dan benar, melainkan memahami pendapat orang lain, yang berpeluang membuat orang lain mau memahami pendapat kita, tanpa harus membenarkannya. Hasil akhirnya ialah: kehidupan yang saling 
memahami dan saling menerima, yang menjadi modal pembangunan bangsa dan bangsa-bangsa yang beradab. Inilah obat anti konflik SARA.

Perlu dicatat pula bahwa hubungan dialogis antar subyek pembangunan, seperti yang dikemukakan di atas, tidak akan menemukan jawaban akhir yang "siap-pakai" di dalam pembangunan. Jawabannya terus berkembang; terus berada di dalam proses penciptaan dan pencipatan kembali dalam perjalanan sejarah. Ungkapannya dalam bahasa Latin adalah: in statu nascendi! Berada di dalam status akan dilahirkan. Itulah dinamika pembangunan yang menggairahkan para pelaku sejarah. Begitu kita yakin bahwa sesuatu pendapat adalah kebenaran akhir yang siap-pakai pada setiap saat dan di setiap tempat, itulah awal terjadinya perbedaan pendapat yang destruktif. Cara berpikir kita menjadi cara berpikir dogmatis yang mati. Seyogianya, iman itu tetap, tetapi penerapannya selalu berada dalam tahap penciptaan dan pen-ciptaan kembali, sesuai dengan konteks di dalam mana kita berada.

Pertanyaan Renungan: Apakah ada contoh hubungan "I-It" dan "IThou" yang dapat dikemukakan berdasarkan peng-alaman pribadi kita masing-masing?

Karena agama dan pengajarannya merupakan salah satu sumber pembentuk motivasi sikap dan perilaku para pelaku pembangunan, maka dialog antar umat beragama menjadi penting - kalau bukan yang paling penting - dalam usaha pembangunan, kini dan di sini.

\section{Keberpihakan Tuhan}

Salah satu modal pembangunan ialah natural factor endowment, yaitu ketersediaan sumberdaya alam. Perbedaan natural factor en-dowment dapat menjadi salah satu sebab perbedaan kemajuan antar- wilayah. Tetapi, Singapura yang miskin sumberdaya alam, dapat menjadi negara maju kelas satu, diapit oleh negara-negara lain yang kaya sumberdaya alamnya, tetapi ketinggalan pembangunannya. Anugerah Tuhan, melalui sumberdaya alam yang berlimpah, bukanlah menjadi jaminan keberhasilan pembangunan sesuatu wilayah.

Pada bulan Agustus 1960, Perdana Menteri Lee Kuan Yew dan rombongannya dari Singapura mengunjungi Indo-nesia. Mereka dilayani Perdana Menteri Indonesia ketika itu, Ir. Djuanda Kartawijaya. Pada suatu diskusi empat mata, Lee Kuan Yew mengatakan kepada Djuanda bahwa Indonesia diberkati Tuhan dengan tanah yang luas, subur, dan iklim yang bersahabat. Djuanda menatap Lee Kuan Yew dengan sedih, lalu 
mengatakan: "Tuhan berpihak kepada kami, tetapi kami sendiri tidak berpihak kepada diri sendiri."

Dari perbedaan pengalaman pembangunan Singapura dan Indonesia dapat kita simpulkan bahwa: Penyebab kemajuan pembangunan sesuatu bangsa terutama bukanlah kelimpahan sumberdaya alam yang dimiliknya, melainkan kesadarannya tentang dirinya dan tugasnya memanfaatkan apa yang dimilikinya secara bertangung-jawab. Bahkan, tanpa kesadaran tersebut, kelimpahan sumberdaya alam justeru dapat menjadi faktor penghambat pembangunan, seperti yang dapat dicontohkan berikut ini.

Pada tahun 2009, seorang mahasiswi Program Doktor ${ }^{11}$ yang saya bimbing, penasaran melihat kenyataan bahwa daerah asalnya, Maluku, yang kaya sumberdaya alamnya, kini masih merupakan salah satu wilayah termiskin di Indonesia. Perhatiannya tertuju pada pola kerja dan pola pikir sekelompok kaum perempuan pedagang yang di Maluku dinamakan papalele. Mereka ini adalah perempuan pedagang yang bekerja keras, menjadi tulang-punggung ekonomi keluarga. Walau pun bekerja keras, di lingkungan yang kaya sumberdaya alamnya, tetapi mereka tetap hidup pas-pasan (subsistence life).

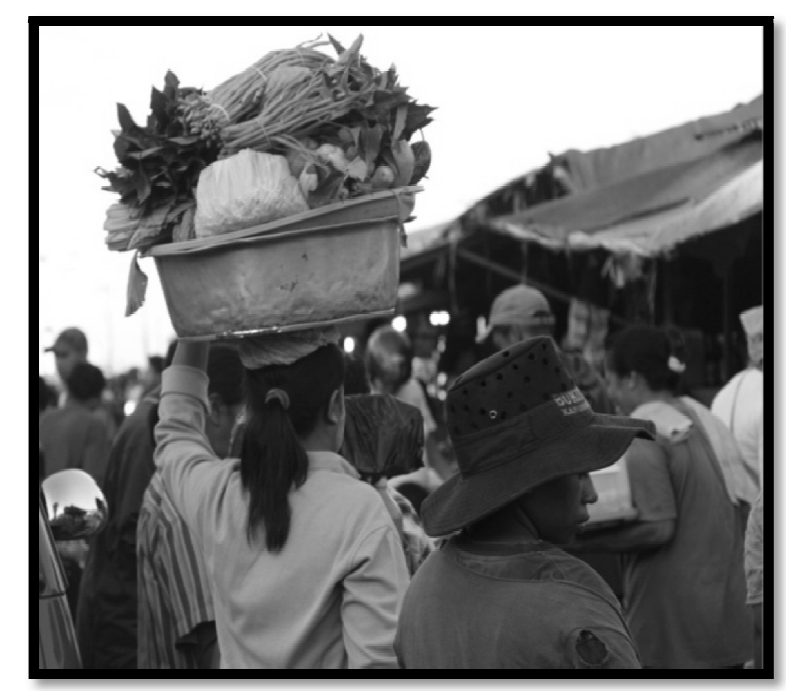

Gambar 6. Perempuan papalele di Ambon; pekerja keras, tulang punggung ekonomi keluarga; hidup pas-pasan.

\footnotetext{
${ }^{10}$ W.I.M. Poli, Kepemimpinan Stratejik; Pelajaran dari Yunani Kuno hingga Bangladesh, 2011: $169-171$.

${ }^{11}$ Dr. Maria Katje Tupamahu, dosen Fakultas Ekonomi, Universitas Pattimura, Ambon. Disertasi (tidak diterbitkan) 2012, berjudul Analisis Perilaku Ekonomi Kelompok Perempuan Papalele di Ambon.
} 
Hasil penelitian menunjukkan bahwa kehidupan mereka yang paspasan bersumber pada pola pikirnya tentang kehidupan yang berkenan di bagi Tuhan. Di bawah ini dikutipkan pendapat dua responden yang beragama Islam:

Responden 1: Semua rejeki itu anugerah Allah SWT dan tidak ada seorang pun yang dapat mengubahnya. Lalu, mengapa mau susah-susah berpikir menjadi lebih kaya? ${ }^{12}$

Responden 2: Hidup, mati, rejeki, itu semua sudah diatur oleh Allah SWT. Jadi, kalau nasib sudah ditentukan, siapa yang mau melawannya? ${ }^{13}$

Ada nada menyerah pada nasib, yang sudah ditentukan oleh Tuhan, yang tidak boleh dilawan. Ternyata pendapat yang sama ditemukan pada responden lainnya, yang beragama Kristen, seperti yang terlihat berikut ini.

Responden 5: Tuhan sudah memberi. Biar pun sedikit, itu adalah berkat yang tidak dapat dilawan. ${ }^{14}$

Responden 7: Kami berjualan tetapi tidak berjiwa pedagang. Kami berjualan sekedar untuk menyambung hidup, bukan untuk memperkaya diri.

Responden 8: Berkat tiap orang itu sudah tiap hari di-sediakan oleh Tuhan. Berkat setiap hari sudah cukup, tidak berlebihan, cukup untuk disimpan sedikit-sedikit dan meng-syukurinya. ${ }^{16}$

Pikiran semacam ini antara lain ditemukan juga dalam sebuah laporan seorang Pekabar Injil di Toraja ${ }^{17}$ pada awal abad XX. Laporan itu antara lain berbunyi sebagai berikut:

Di mana saja saya tinggal dalam perjalanan ini hal pokok yang sama saya uraikan, yakni perumpamaan orang bodoh yang kaya dari Lukas 17. Di mana saja cerita ini saya sampaikan secara sejalas-jelasnya, Kekayaan orang itu dibentangkan sejelas-jelasnya. Lumbung-lumbungnya ber-tambah banyak terus; lumbung-lumbung itu berdiri berbaris di depan rumahnya

\footnotetext{
${ }^{12}$ Ibid., 133.

${ }^{13}$ Ibid., 166.

${ }^{14} \mathrm{Ibid} ., 247$.

${ }^{15}$ Ibid., 289.

${ }^{16}$ Ibid., 304.

${ }^{17}$ Antonie Aris van de Loosdrecht (1885-1917).
} 
sehingga setiap orang yang datang di kampung bertanya dengan amat heran: siapakah gerangan yang menjadi pemilik lumbung-lumbung padi ini? dan jawabannya selalu berbunyi: "Pare la'bi" (dia yang padinya bertambah terus). ${ }^{18}$

Topik tersebut di atas disampaikan di mana-mana pada setiap perkunjungannya. Topik ini sangat gampang dimengerti dan menarik perhatian para pendengarnya, karena memang di dalam kebiasaan masyarakat Toraja, orang mendirikan lumbung padinya terlepas dari rumah tempat tinggalnya, yang gampang terlihat orang lain dari luar. Setelah orang tertarik perhatiannya, Pekabar Injil itu menyudahi penuturannya dengan mengatakan bahwa orang kaya itu adalah orang yang bodoh di mata Tuhan. Dengan bangga ia antara lain menuturkan kepada para pembacanya di negeri Belanda sebagai berikut:

... khalayak ramai seperti tersambar halilintar waktu saya menunjukkan arti perumpamaan itu bagi mereka. Berita seperti itu sama sekali baru bagi mereka. Orang itupun pada terpukul. Selanjutnya dengan mulut menganga didengar-kannya penjelasan saya dan alasan-alasan mengapa orang itu bodoh di mata Allah. Bahwa Allah mengasihi orang miskin sama seperti orang kaya, nah, hal itu belum pernah timbul dalam benak orang Toraja. Hal itu benar-benar merupakan berita yang amat baru. ${ }^{19}$

Kita tidak meragukan maksud baik sang Pekabar Injil tersebut di atas. Ia telah bekerja dengan keyakinan penuh tentang kebenaran Injil yang diberitakannya. Tetapi, perlu kita bayangkan, apakah yang terjadi di dalam pikiran para pendengarnya, dan apa kemungkinan akibatnya? Salah satu kemungkinannya ialah: pendengarnya mengidealisasikan kemiskinan, dan mengharamkan kekayaan material. Lazarus yang miskin diidolakan karena akan masuk surge. Orang miskin mendapat alasan yang bagus untuk membenarkan kemiskinannya. Orang miskin tidak perlu berusaha mengatasi kemiskinannya, karena ia dikasihi oleh Tuhan, dan ia akan masuk surga. Bukan ia yang bodoh, melainkan orang yang kaya. Apakah hal ini relevan di tengah-tengah kemiskinan material yang ada sekarang ini di Indonesia? Siapakah yang berani menghibur ibubapak balita yang mati karena kekurangan gizi, dengan mengatakan: "Janganlah sedih! Tuhan mengasihi orang miskin! Anakmu menderita di dunia, dan mati, tetapi ia akan masuk surga!"

\footnotetext{
${ }^{18}$ Th. Van den End, Sumber-Sumber Zending tentang Sejarah Gereja Toraja 1901-1961, 1994: 97.

${ }^{19}$ Ibid., 98.
} 
Pertanyaan Renungan: Di tengah-tengah kemiskinan yang ada sekarang ini di Indonesia, mana yang perlu ditekankan: kesalehan orang miskin ataukah pengembangan talenta oleh hamba yang setiawan?

\section{Kerendahan Hati}

Kesimpulannya ialah: di tengah-tengah kemiskinan di Indonesia sekarang ini, masih banyak yang harus kita lakukan, menuju masa depan yang lebih bermakna. Kita terpanggil untuk berusaha dengan modal "lima ketul roti dan dua ekor ikan", yang ada pada kita. Tetapi, apa pun yang kita usahakan, tidak seorang pun yang dapat dengan pasti meramalkan masa depan yang lebih bermakna. Hal ini juga disadari sepenuhnya oleh almarhum Soedjatmoko (1922-1989), Duta Besar RI di Amerika Serikat (1968-1971), dan Rektor Universitas PBB (1980-1987). Ketika berbicara di sebuah pertemuan internasional yang membicarakan masa depan Indonesia setelah 45 tahun merdeka, ia antara lain mengatakan:

Di dalam perjalanan sejarah tidak seorang pun yang dapat memastikan akibat-akibat jangka panjang dari pilihannya, karena masa depan tidak dapat diprediksi. Hal ini juga berlaku ketika kita harus membuat pilihan akhir: apakah bergabung dengan kekuatan utama arus sejarah, atau memilih sebuah sudut yang kurang berarti, ataukah terlibat dalam berbagai arus yang berlawanan arah. Apa pun pilihannya, tidak ada hasil akhirnya yang pasti. Karena itu, tampaknya, satu-satunya dasar pengambilan keputusan adalah keyakinan dan nilai-nilai yang dianut, dan dengan penuh kerendahan hati. $^{20}$

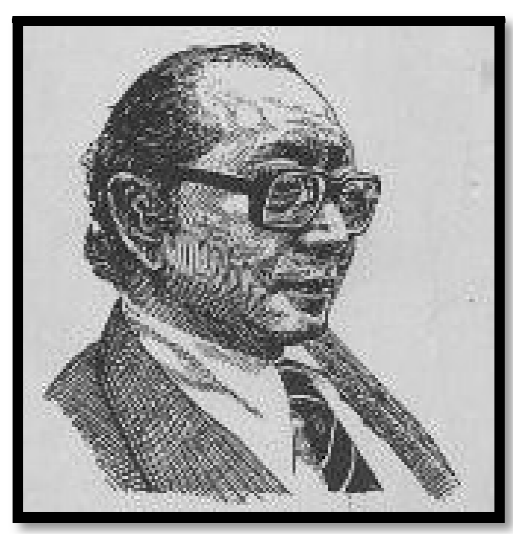

Gambar 7. Soedjatmoko: Kerendahan Hati.

\footnotetext{
${ }^{20}$ Soedjatmoko, "Choices and Circumstances. The Indonesian Revolution 45 years on: Some Personal Reflections"; di dalam The Decolonization of Indonesia; International Perspectives; Roosevelt Study Center/Stichting V.O.C.,Publicaties Zeeland, Middelburgh, 1988, hal. 22.
} 
Pendapat Soedjatmoko tersebut sejalan dengan pendapat Karl Paul Reinhold Niebuhr (1892-1971), seorang teolog besar abad XX dari Amerika Serikat, yang pendapatnya banyak dikutip oleh Soedjatmoko di dalam berbagai tulisannya tentang pembangunan. Dengan latarbelakang pengalaman Niebuhr tentang penindasan yang dialaminya pada masa pemerintahan Hitler, dan pengalaman hidup di lingkungan perang dingin setelah Perang Dunia II, ia berbicara tentang realitas yang dihadapi umat manusia di dalam dunia ini. Di satu pihak ada cita-cita besar tentang masa depan yang gemilang, berdasarkan iman yang dianut. Di lain pihak perlu adanya kesediaan menghadapi kenyataan tertentu, yang tidak diinginkan tetapi juga tidak dapat diubah. Menyadari tentang adanya kenyataan sedemikian ini, ia menulis apa yang kini luas dikenal sebagai Serenity Prayer, "Doa Kerendahan Hati":

Ya Tuhan, berikanlah kepadaku: kerendahan hati untuk menerima apa yang tidak dapat saya ubah; keberanian untuk mengubah yang dapat saya ubah; dan kearifan untuk dapat membedakan yang satu dari yang lainnya.

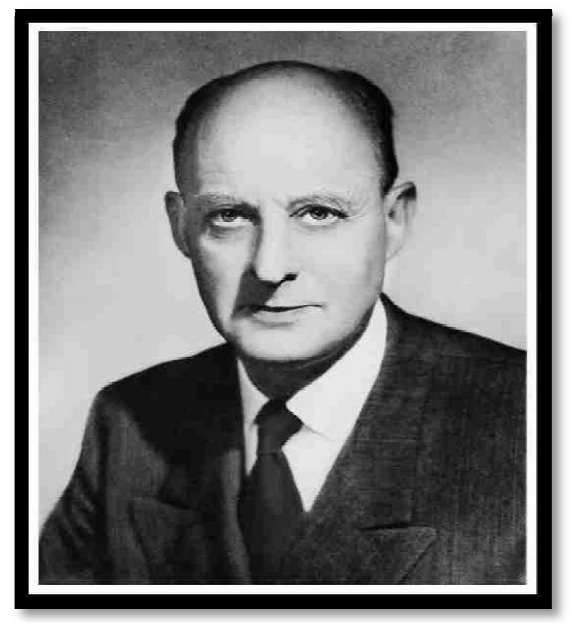

Gambar 8. Reinhold Niebuhr (1892-1971).

Karena kita harus berbuat sesuatu di lingkungan di mana kita berada (ciri kontekstual), dan mungkin saja kita kurang dapat membedakan mana yang dapat diubah dan mana yang tidak dapat diubah, maka kita juga harus siap menerima kegagalan, sebagai sumber pembelajaran untuk langkah berikutnya.

${ }^{21}$ Ada yang meragukan bahwa Serenity Prayer adalah karya asli Niebuhr. Walau pun demikian, tidak dapat disangkal bahwa Niebuhrlah yang mengglobalisasikannya. 


\section{Realitas Baru}

Walau pun masa depan tidak pasti, kita harus membuat pilihan bersama, kini dan di sini, untuk menyongsongnya. Dalam hal ini, sebuah pepatah Brazil dapat menguatkan keyakinan kita dalam membuat pilihan bersama. Katanya:

When we dream alone, it is just a dream. But when we dream together, it is the beginning of a new reality.

Jika kita mimpi sendirian, itu hanyalah sebuah mimpi, Tetapi, jika kita mimpi bersama, itu adalah awal dari sebuah realitas baru.

Dengan mimpi bersama, yang dijabarkan ke dalam tindakan di lingkungan kerja kita masing-masing di bumi Indonesia, dapatlah kita berdoa dengan gembira - bukan dengan takut - mengatakan: Datanglah Kerajaan-Mu; jadilahlah kehendak-Mu di dalam dunia, seperti juga di dalam surga! Inilah inti Teologi Pembangunan yang Eskatologis dan Kontekstual.

\section{Kesimpulan}

Dari uraian yang telah dikemukakan dapat diturunkan lima kesimpulan berikut ini.

Pertama, Teologi Pembangunan yang Kontekstual adalah uraian tentang usaha manusia membebaskan diri dari ketidakmampuan sendiri dan orang lain, menuju kehidupan bersama yang lebih bermakna di dalam lingkungannya, berdasarkan iman yang dianut.

Kedua, berdasarkan iman yang dianut, kegiatan pembangunan yang kontekstual bersifat eskatologis, yaitu kegiatan menuju kesempurnaan Kerajaan Allah di dalam Yerusalem Baru.

Ketiga, pemecahan masalah pembangunan seyogianya mengandalkan kemitraan semua pelaku pembangunan di dalam masyarakat majemuk yang beradab.

Keempat, dengan kerendahan hati setiap pelaku pembangunan seyogianya menerima kenyataan bahwa tidak semua masalah dapat dipecahkan.

Kelima, walau pun masa depan tidak dapat diprediksi, tetapi melalui kemitraan para pelaku pembangunan di dalam masyarakat majemuk yang beradab, kita dapat menyongsong masa depan sebagai sebuah realitas baru. 


\section{Kepustakaan}

Buber, Martin. I and Thou; terjemahan Ronald Gregor Smith. Edinburgh: T. \& T. Clark, 1937.

End, Th. van den. Sumber-Sumber Zending tentang Sejarah Gereja Toraja 19011961. Jakarta: BPK Gunung Mulia, 1994.

Orwell, George. Nineteen Eighty-Four. England: Penguin Books, Harmondsworth, Middlesex, 1954.

Poli, W.I.M. Manajemen Stratejik melalui Cerita Kecil. Surabaya: Brilian Internasional, 2011.

Poli, W.I.M. Kepemimpinan Stratejik; Pelajaran dari Yunani Kuno hingga Bangladesh. Makassar: Identitas, 2011.

Raskin, Paul D. The Great Transition; A Report from the Future. Boston, MA: Tellus Institute, 2006.

Soedjatmoko. Pembangunan dan Pembebasan. Jakarta: LP3ES, 1984.

Soedjatmoko. Etika Pembebasan. Jakarta: LP3ES, 1984.

Soedjatmoko. "Choices and Circumstances." The Indonesian Revolution 45 years on: Some Personal Reflections"; di dalam The Decolonization of Indonesia; International Perspectives. Roosevelt Study Center/Stichting V.O.C. Middelburgh: Publicaties Zeeland, 1988.

Tupamahu, Maria Katje. Disertasi: Analisis Perilaku Ekonomi Kelompok Perempuan Papalele di Ambon, 2012. Tidak diterbitkan. 